\title{
The Low-Carbon and Environmental Protection of Textile and Garment in China
}

\author{
Aili Zhu, Yue Hu* \\ Shanghai University of Engineering Science, Shanghai, China \\ Email: ^2540755339@qq.com
}

How to cite this paper: Zhu, A.L. and $\mathrm{Hu}$, Y. (2016) The Low-Carbon and Environmental Protection of Textile and Garment in China. Journal of Geoscience and Environment Protection, 4, 45-49.

http://dx.doi.org/10.4236/gep.2016.411005

Received: August 26, 2016

Accepted: November 1, 2016

Published: November 4, 2016

Copyright (c) 2016 by authors and Scientific Research Publishing Inc. This work is licensed under the Creative Commons Attribution International License (CC BY 4.0).

http://creativecommons.org/licenses/by/4.0/

\begin{abstract}
It should be transformed from the extensive development in the past to the new normal form of environmentally friendly pattern of "save energy, lower consumption and less pollution" in the Textile and Garment. For the pollution problem in China's textile and garment industry, the author particularly analyzes the pollution of the textile and garment industry mainly occurred in the process of textile and clothing production and sales in this article. Finally, the author puts forward detail measure to control the pollution from the two aspects and advocates the concept of low-carbon environmental protection and green lifestyle. The low-carbon environmental protection has become a phenomenon in Textile and Apparel.
\end{abstract}

\section{Keywords}

Textile and Garment Industry, Environmental Pollution, Energy Saving, Green Environmental Protection

\section{Introduction}

Gui-Zhen Yao wrote in "Measures Taken by Textiles and Fashion Enterprises in China against the Pressure of Low-Carbon Environment Protection": pollution of sewage occurring in dying and finishing process on environment is increasingly aggravating, and three corresponding strategies were proposed (innovation technology, converting conception and extensive publicity) [1]. This article analyzes the exhaust fumes, effluent, noise, dust, fabrics of solid waste and packaging waste from textile mill and the manufacturing and selling processes seriously polluting the environment, and provides five solutions.

With the deepening of industrialization, environmental pollution becomes more and 
more serious and it has been a serious threat to human living environment. China has been the largest producer, consumer and exporter of clothing in the world. China's textile and garment industry as a strong motive to meet the demands of National dress solves the problem of unemployment and promotes the increase of our GDP [1] [2] [3]. At the same time, the pollution of the textile and garment industry has caused serious damage on environment. With rapid development of textile and apparel industry, environment pollution becomes more and more prominent. Accordingly, it must optimize the industrial structure and construct environmental friendly pattern.

\section{The Pollution of Textile and Garment Industry}

Textile and garment industry pollution is in the forefront in the industrial sector. The pollution mainly occurred in the textile and clothing production/sales process links [4] [5].

\subsection{In the Textile Link}

Fiber production and dyeing and finishing are the two main links in the process of textile production, these processes produce much waste gas, waste water and noise.

1) According to incomplete statistics, the wastewater emissions from printing and dyeing in China is about $3 \times 106$ to $4 \times 106 \mathrm{~m}^{3}$ per day, will have $3-5$ tons wastewater a day form dyeing $100 \mathrm{~m}$ fabric, the pollution of printing and dyeing wastewater is particularly serious. It is characterized with great variation in temperature and volume of water, complicated component, high colority, high pollutant concentrations and poor biological degradability. The waste water, which contains large amounts of harmful substances, can directly affect human health. Formaldehyde, printing and dyeing auxiliaries in the fabric could cause a headache, skin allergies and other symptoms. Some aromatic amine intermediates, heavy metals and preservative are "possibly carcinogenic" to humans, and they effect on the growth of aquatic and microbiological can destroy the equilibrium of ecosystem of water and cause land salinization.

2) The pollution of textile and garment industry mainly from two aspects: one is the spinning technology of chemical fiber, and it will release plenty of harmful gas such as nitrogen dioxide, sulfur dioxide, hydrogen sulfide and other harmful gases during the spinning. the other is pretreatment of textile and finishing processes of producing, the VOCs (it mainly involves formaldehyde, benzene, aromatic hydrocarbons and so on) are produced in the process of production, which also one of the important components of PM2.5 and has caused serious harm to the atmospheric environment. According to the statistics, emissions from textile mill have increased to over 190,000 tons in 2011 from 70,000 tons in 2001, the exhaust gases lead to serious harm to the atmospheric environment.

3) The noise from a lot of textile machinery is used in textile workshops. The noise of the machine vibration meets 90 decibels or more. The volume of beyond 80 decibels can damage auditory organ from a medical standpoint. Noises can have a significant adverse impact on the workers' living. For workers, stay strong noise environment long 
may lead to neurasthenia such as dizziness, tinnitus, insomnia, hypomnesis and even death.

\subsection{Pollution from the Manufacturing and Selling Processes}

It has three main sections: dust pollution, fabrics of solid waste and Packaging waste, etc. there's so many mill dust during cutting fabric. It sure incites workers' respiratory disease who stays in such an environment for the long-term. In the designing and making, the large number of surplus material according to unreasonable cutting, thousands of tons of fabrics are wasted every year. The material of packaging in the common market briefly cover: OPP, CPP, PE and other kinds of plastic bags and composite bags; PVC shrinkable film, Printing film, packaging film, EPE bubble film, EPE bubble bag. These materials cannot be recovered some similarities and hardly degradable.

\section{Ways of Coping with Low Carbon Environmental Pressure in the Textile and Garment Industry}

In1980s, Human taste the bitter fruit of environmental damage, low carbon environmental protection and green ideas have infiltrated into every walk of life along with the people's consciousness of environmental protection. These concepts have also been introduced into the textile and garment industry which have become one of the popular trends. Our country is in the changing process from big country to powerful country of textile and clothing. The extensive operation based on the low cost labor and high consumption and low production has been difficult to continue. Now, the industry insider agrees that calls for shifting the development model and optimizing industrial structures. It is an important prerequisite of sustainable development that builds the amicable type of environmental development pattern. This paper puts forward the development of green economy in the textile and garment industry can be started with the followings [6] [7] [8].

\subsection{The Raw Material}

The textile factories must promote clearer production, research and development environment-friendly materials and the fabrics of low carbon (such as organic cotton, colored cotton, bamboo fiber, soybean protein fiber, hemp fiber, modal fibre and so on); develop available recycled fibers, to restrict produce toxic and harmful clothing materials, dyeing auxiliaries and detergents. The business through uses the advanced fiber production, dyeing and finishing designing and machining, reducing environmental pollution as far as possible, curbs the use of rare animal fur as clothing materials.

\subsection{The Energy Sources}

To reduce coal-fired boiler usage, the textile mills can use bioenergy, wind power, hydraulic and other renewable energy resources instead of traditional fossil fuels with high carbon content. 


\subsection{The Management of Industrial}

The cotton mills need put rational distribution, improve textile technology and exploit low-noise new mechanical, workshops install sound-absorbing device, sound arrester and silencer. Garment factories keep clean and ventilation. Individual requires the awareness to protect themselves and wears dust mask.

\subsection{The Change of Design Concept}

It is the mission entrusted by the times and the demand of people for their health Life that designers must incorporate the low-carbon concept into design. Designers have the principle of economizing and low-carbon. It is advocated the second design of outside material in clothing design, the dress accessories are used again and the second design of old clothes, so they greatly prolong the working life of the clothing. Fashion designers Establish the design concepts of the surplus of fabrics and one outfit to wear more Multi-use of one for reducing material resources to waste.

\subsection{The Green Package}

The enterprises optimize the packaging structure for convenient transport that take decreasing package and low-carbon packaging that the packages are used little or not, and use a non-toxic (packing materials are harmless to human beings) and pollution-free and easy recovery, reusable, easily biodegradable material. Non-damaging Packaging is inexorable trend of packaging market development in China.

\section{Conclusions}

The textile clothing industry is one of the backbone industries of consumer goods. But environmental problem does harm to our sustainable development strategy and green dream of home. In order to actually diminish the pollution of environment, it is urgent to control the pollutant produced in the industry. Meanwhile, relevant government department should oversee enterprise's blowdown situation. Environmental protection departments at all levels formulate a set of Low-carbon production appraisals incentive mechanism that encourages and supports green innovations from the aspect of policy.

Energy conservation and environment protection is a topic paid attention by China and the west and the focus of the fashion business. Chinese textile industry takes effective measures to solve the problem of pollution that has reached a critical state. At macroeconomic level, the Chinese people can strengthen the guiding policies and adjust structure from headstream of information industry, and apply energy efficient ecoeconomics to turn the green dream into a reality.

\section{References}

[1] Yao, G.-Z. (2011) Measures Taken by Textiles and Fashion Enterprises in China against the Pressure of Low-Carbon Environment Protection. Zhejiang Textile \& Fashion Vocational College, 10, 74-77.

[2] Zheng, G.-F., Ma, M.-T., Xu, L. and Shen, X.-Y. (2004) The Pollution and Environmental 
Strategy for China's Textile Industry. Environmental Pollution \& Control, No. 6, 480.

[3] Wang, T. (2013) Preliminary Analysis of Low-Carbon Environment Protection Concept of Packing Design of Clothing Products. Beauty \& Times, No. 8, 62.

[4] Wu, Y.-H. (2010) Ecologically-Based Fashion Design. China Textile Leader, No. 10, 94-96.

[5] Ao, J.-F., Zhao, D.-C. and Yan, G. (2013) Traditional Textile Printing and Dyeing Industry Face to Challenge. China Fiber Inspection, No. 7, 50-53.

[6] Loo, C. (2010) Elementary Analysis on Noise of Textile Workshop \& Noise Reduction Measures. Shandong Textile Science \& Technology, 51, 39-41.

[7] Zhu, H., Jie, S. and Li, J.-C. (2004) Techniques of Dyeing Wastewater Treatment. China Textile \& Apparel Press, No. 9.

[8] Zhang, J. (2007) Beneath Modern Logistics of Prosperity. China Logistics \& Purchasing, No. 7 .

Submit or recommend next manuscript to SCIRP and we will provide best service for you:

Accepting pre-submission inquiries through Email, Facebook, LinkedIn, Twitter, etc.

A wide selection of journals (inclusive of 9 subjects, more than 200 journals)

Providing 24-hour high-quality service

User-friendly online submission system

Fair and swift peer-review system

Efficient typesetting and proofreading procedure

Display of the result of downloads and visits, as well as the number of cited articles

Maximum dissemination of your research work

Submit your manuscript at: http://papersubmission.scirp.org/

Or contact gep@scirp.org 